\section{B A Institute of \\ YK Business Administration \\ 六下 \\ Karachi \\ Leadership and Ideas for Tomorrow}

Business Review

Volume 6 Issue 1 January-June 2011

$1-1-2011$

\title{
Integration management for green business to achieve sustainability and buildability
}

\author{
Low Sui Pheng \\ National University of Singapore, Singapore \\ $\mathrm{Ng}$ Wei Chen \\ National University of Singapore, Singapore
}

Follow this and additional works at: https://ir.iba.edu.pk/businessreview

Part of the Business Commons, and the Human Ecology Commons

(c) (i)

This work is licensed under a Creative Commons Attribution 4.0 International License.

\section{Recommended Citation}

Pheng, L., \& Chen, N. (2011). Integration management for green business to achieve sustainability and buildability. Business Review, 6(1), 27-50. Retrieved from https://doi.org/10.54784/1990-6587.1180

This article is brought to you by iRepository for open access under the Creative Commons Attribution 4.0 License and is available at https://ir.iba.edu.pk/businessreview/vol6/iss1/3. For more information, please contact irepository@iba.edu.pk. 


\title{
ARTICLE
}

\section{Integration Management for Green Business to achieve Sustainability and Buildability}

\author{
Low Sui Pheng and Ng Wei Chen \\ National University of Singapore, Singapore
}

\begin{abstract}
The Building Control (Environmental Sustainability) Regulations, introduced in 2008, require buildings to attain minimum scores under the Green Mark Scheme (GMS) in Singapore. The Building Control (Buildable Design) Regulations, introduced in 2001, require buildings to attain minimum buildability scores under the Buildable Design Appraisal System (BDAS) in Singapore. It appears that both the GMS and BDAS can influence building designs and must therefore be considered concurrently to yield the optimal results. Consideration of both sets of requirements is illustrated using a case study of one 18-storey residential building. Through interviews, the study also explores the issues relating to integration management for green business, i.e. if architects consider BDAS and GMS requirements at the design conceptualization stage. The case study suggests a slight decrease in the buildability score when modifications were made to lower the residential envelope transmittance value (RETV) to obtain a higher Green Mark score. The interviews seem to suggest that architects do not consider BDAS and GMS requirements concurrently. Instead, they seem to think that considerations for BDAS and GMS do not have significant effect on each other and that on the contrary these might even complement each other.
\end{abstract}

\section{INTRODUCTION}

The challenge for environmental sustainability has been both a global and national concern. In Singapore, the National Environment Agency (NEA) has responded with the National Climate Change Strategy that presents Singapore's current and future efforts to address climate change, and to mitigate the emissions of greenhouse gases. In the construction industry, the Building and Construction Authority (BCA) first launched the Green Mark Scheme (GMS) for buildings in January 2005 to promote environmental sustainability in buildings to encourage the use of various green building designs, technologies and innovations. This helps to reap benefits such as cost savings from energy usage and water consumption, reduce potential impacts on the environment and improve the indoor environment quality of the workplace. 
A part from environmental issues, Singapore's construction industry also faces issues relating to low productivity. As the BCA continues to push forth sustainable developments through the GMS, green features will no longer be neglected in building designs. To achieve Green Mark certification, building designs need to fulfill a set of mandatory requirements assessed by the BCA. The extent to which green building designs are incorporated will be reflected in the resultant scores after the assessment qualify buildings for different Green Mark ratings. In 2008, the Building Control (Environmental Sustainability) Regulations was introduced, making it compulsory for building designs to achieve specified minimum Green Mark scores before their building plans can be approved by the authorities.

In addition, the Building Control (Buildable Design) Regulations, introduced in 2001, require building designs to achieve minimum buildability scores before their building plans can be approved by the authorities. The implication is that new developments will now need to take into consideration both sets of mandatory requirements from the GMS and the BDAS or the Buildable Design Appraisal System. It appears that having to fulfill the mandatory requirements to achieve Green Mark certification can in turn affect the buildability scores, and vice versa. However, it seems that the considerations in both design domains are currently being compartmentalized or at best considered separately.

Consequently, there is a need to examine the extent to which these two sets of design parameters will affect each other for designers to work efficiently towards achieving environmental sustainability and buildability.

The objectives of this study are to:

1. Examine the implications on buildability scores when the GMS requirements are being considered concurrently.

2. Explore integration management relating to the application of BDAS and GMS requirements concurrently during the design conceptualization stage.

For simplicity, this research will only examine one mandatory requirement from the GMS, specifically for residential buildings. The mandatory requirement relates to the thermal performance of the building envelope where the maximum permissible residential envelope transmittance value (RETV) is $25 \mathrm{~W} / \mathrm{m}^{2}$.

\section{BUILDABILITY IN SINGAPORE THROUGH BDAS}

The low productivity rate in the construction industry in Singapore led the building authorities to popularize the concept of "buildability" which would enable the industry to raise its productivity. A buildable design is driven by three principles, namely Standardization, Simplicity and the Single Integrated Elements, otherwise 
known as the "3S Principles of Buildable Design". Standardization refers to the repetition of grids, sizes of components and connection details. A repeated layout, for example, will facilitate faster construction when formwork or precast concrete components are used. Similarly columns or external claddings of repeated sizes will reduce the number of mould changes whether on-site or in the factory [1]. Simplicity means uncomplicated building construction systems and installation details. A flat plate system for example, eases formwork construction as well as reinforcement works considerably. The use of prefabricated components reduces many trade operations on site and should improve site productivity provided the standardization principles are observed [1]. Single integrated elements are those elements that combine related components together into a single element that may be prefabricated in the factory and installed on site. Precast concrete external walls, curtain walls or prefabricated toilets are good examples of this principle [1]. With the use of these $3 \mathrm{~S}$ principles, a design with higher buildability can be achieved.

The BDAS serves as a means to measure the potential impact of a building design on the usage of site labour. It would then result in a "Buildability Score" of the design for new and existing buildings, with a maximum achievable score of 100 points. A higher score achieved would mean that there is more efficient labour usage in the construction and thus higher site labour productivity. Although it is the aim of the BDAS to have wider use of buildable designs, good architectural designs should not be compromised. Most importantly, the ultimate goal is to have improvements in quality through buildable designs. The computation in the buildability score consists of three components:

1. Structural System - with a maximum of 50 points which requires the building designer to use different structural systems for the most practical design;

2. Wall System - with a maximum of 40 points which requires the designer to use different wall systems for the most practical design; and

3. Other Buildable Design Features - with a maximum of 10 points which takes into consideration the level of standardization of columns, beams, windows and doors, together with grids and usage of precast components [1].

Within these three components, a Labour Saving Index (LSI) is given to each building system and also for the use of prefabricated reinforcement cages in cast in-situ component. A high index implies that the design is more buildable and fewer site workers are needed. Using these indices, and measurements of the components, the buildability score is then calculated. Due to space limits, it suffices to say that a detailed example of buildability score computation can be found in the Code of Practice for Buildable Design [1] and will not be elaborated here. 
Legislation for the BDAS is facilitated through the Building Control (Buildable Design) Regulations 2001 leading to the approval of building plans. Section 5 of the regulations makes submission of the buildability scores to the Commissioner of Building Control compulsory and should be endorsed by all the qualified persons. Under the Building Control Act, the "Qualified Person" means a person who is registered as:

(a) An architect under the Architects Act (Cap. 12) and has in force a practicing certificate issued under that Act; or

(b) A professional engineer under the Professional Engineers Act (Cap. 253) and has in force a practicing certificate issued under that Act.

In addition, the buildability score of the development needs to comply with the minimum score provided in the Code. Different minimum scores are applicable across different categories of building development and gross floor areas.

\section{SINGAPORE'S GREEN MARK SCHEME}

As of 2005, commercial and institutional buildings accounted for $16 \%$ of Singapore's $\mathrm{CO}_{2}$ emissions (largely from cooling and lighting functions) [2]. In order to reduce this percentage of $\mathrm{CO}_{2}$, the BCA first launched the Green Mark for Buildings Scheme (Green Mark) in 2005 as a bold initiative to move Singapore's building and construction industry towards environment-friendly buildings and help strengthen Singapore's position as a global city committed to balancing its development with care for the environment [3].

The Singapore government introduced the Building Control (Environmental Sustainability) Regulations together with the Code for Environmental Sustainability of Buildings [4] specifically for this purpose. The legislation requires the building owners or developers to engage relevant personnel to assess and tabulate a Green Mark score which will be indicted during the submission of building plans for approval by the BCA. The Code sets out the minimum environmental sustainability standard that is on par with the Green Mark Certified standard for buildings and includes the compliance method for determining the level of environmental performance of a building development [5].

At the end of the Green Mark assessment exercise, the score obtained will allow the building development to be eligible for different ratings namely: GM Certified, Gold, Gold Plus and Platinum. 
Based on the GMS, the environmental performance of a building is assessed based on five criteria namely:

1. Energy Efficiency - This category focuses on the approach that can be used in the building design and system selection to optimize the energy efficiency of buildings [5].

2. Water Efficiency - This category focuses on the selection of water use and its efficiency during construction and building operations [5].

3. Environmental Protection - This category focuses on the design, practices and selection of materials and resources that would reduce the environmental impacts of built structures [5].

4. Indoor Environmental Quality - This category focuses on the design strategies that would enhance the indoor environmental quality which includes air quality, thermal comfort, acoustic control and day-lighting [5].

5. Other Green Features - This category focuses on the adoption of green practices and new technologies that are innovative and have potential environmental benefits [5].

Since its launch in 2005 , the BCA has been actively promoting sustainable development to the private sector in the construction industry through the numerous incentives given, apart from regulations. For example, the Green Mark Incentive Scheme was offered in 2006 as direct monetary incentives to developers who achieved a green building rating above the basic certified level. The Ministry of National Development launched a \$50 million R\&D Research Fund to encourage research into the development of more viable and cost-effective green building technologies and energy efficiency solutions [6]. The BCA also launched the BCA Green Mark Champion award in 2008 to recognize the leaders amongst developers and building owners in Singapore's green building movement. Apart from recognizing the developers, the contractors were also recognized for their environmental efforts with the Green and Gracious Builder Awards introduced in 2009 [6]. In addition, the $2^{\text {nd }}$ Green Building Master Plan included a new incentive scheme: the Green Mark Gross Floor Area (GM GFA) Incentive Scheme which awards additional gross floor area to developers who earned higher-tier Green Mark awards for new buildings and reconstruction projects [6]. Furthermore, a $\$ 100$ million Green Mark Incentive Scheme for Existing Buildings (GMIS-EB) was introduced to encourage private building owners of existing buildings to undertake retrofits to achieve significant improvement in energy efficiency [6]. A target was set to encourage at least $80 \%$ of existing buildings to be GM certified by 2030 . With all these drivers in place, it will not be long before the aim of the developers is not just to meet the minimum requirements for the GMS but to push further for higher standards of environmental sustainability in buildings. 


\section{INTEGRATION OF BDAS AND GMS}

The scope of this paper is limited to examining two mandatory requirements under the GMS which relates to firstly, the thermal performance of the building envelope in residential buildings and; secondly, the indoor comfort of dwelling units which will be further elaborated. These requirements under the GMS will be considered concurrently with its impact on the three components from the BDAS. The reason for examining the requirements for the thermal performance of building envelope specified in the Code for Environmental Sustainability of Buildings lies in the relatively high allocation of points in this domain compared to the other criteria (see Appendix A). In addition, there is also a greater relevance for integration between the GMS and the BDAS here. The thermal performance is determined by the residential envelope transmittance value (RETV) and where building designers are encouraged to design different façade or wall systems with lower RETV. At the same time, the Wall System component from the BDAS should also be taken into consideration by selecting a wall system that has a higher Labour Saving Index. Considering the requirement to enhance the indoor comfort of dwelling units, the layout of the residential units should provide adequate openings for good ventilation which would in turn affect the Wall System component in the BDAS. Therefore, the commonalities between the GMS and the BDAS in this context would possibly allow for integration to enhance the efficiency of design development in building projects.

The following requirements from the GMS suggest some linkages with the components in the BDAS. With reference to the Code for Environmental Sustainability for Buildings, under Part 5 Other Green Features, Environmental Protection,

1. Use of precast toilets with higher points awarded for higher percentage used within the building. Under the BDAS, the use of prefabricated bathroom or toilet units will also allow more points to be awarded.

2. Provision of green roof and roof top garden result in points awarded under the GMS and at the same time, this can in turn affect the scoring for the sub-category, "Roof System", under the "Structural System" component in the BDAS.

3. Provision of vertical greening will allow points to be awarded under the GMS and this can affect the scoring under the "Wall System" component in the BDAS.

Arising from the above analysis, Figure 1 shows the possible requirements that overlap between the GMS and the BDAS. Hence, it can be observed that there is a need for concurrent considerations in design development between the GMS and the BDAS to ensure that the designs for environmental sustainability are not drawn 
up at the expense of buildability and vice versa. The bold arrows in Figure 1 show the two mandatory requirements from the GMS that are being considered in this study and the normal arrows show the possibility of other requirements in the GMS having an impact on the BDAS.

\section{CASE STUDY}

The aim of this case study is to provide further examination of the requirements in the GMS and the BDAS, identify any effects they have on each other and the extent of these effects. For the purpose of this paper, only the criteria for energy efficiency will be considered within the scope of this study. This can be justified by the significant amount of points allocated to energy efficiency. Appendix A shows the framework, and point allocations for the criteria in the residential building category. It can be seen that out of 100 points, 65 points have been allocated to the criteria under energy efficiency notwithstanding the bonus points. In addition, design considerations for energy efficiency can be related to buildability more readily than the rest of the criteria. Furthermore, only the "RB 1-1 Building Envelope - RETV" will be examined in details with its effect on buildability because this has higher points allocated within the Energy Efficiency criteria.

The case study will make reference to the hypothetical example given in the Code of Practice on Buildable Design. The project with a buildability score of 81 points consists of a single block residential building that is 18 -storey high with no basement. Each storey is assumed to be of a typical floor layout with five residential units per storey. The floor-to-floor height is $3.3 \mathrm{~m}$, except the $1^{\text {st }}$ storey, which is $4 \mathrm{~m}$ high (see Figure 2). Figure 2 shows the typical floor layout of each level and the formula for the buildability score is given as follows:

$B S=50\left[\Sigma\left(A_{s} x S_{s}\right)\right]+40\left[\Sigma\left(L_{w} x S_{w}\right)\right]+N+$ Bonus Points

Where:

$\mathrm{A}_{\mathrm{s}}=\mathrm{A}_{\mathrm{sa}} / \mathrm{A}_{\mathrm{st}}$

$\mathrm{L}_{\mathrm{w}}=\mathrm{L}_{\mathrm{wa}} / \mathrm{L}_{\mathrm{wt}}$

$\mathrm{A}_{\mathrm{s}}=$ Percentage of total floor area using a particular structural system

$\mathrm{A}_{\mathrm{st}}=$ Total floor area which includes roof (projected area) and basement area

$\mathrm{A}_{\mathrm{sa}}=$ Floor area using a particular structural system 


\begin{tabular}{|c|c|}
\hline $\begin{array}{l}\text { Green Mark Scheme (GMS) } \\
\text { Residential Building Criteria }\end{array}$ & $\begin{array}{c}\text { Buildable Design Appraisal } \\
\text { System (BDAS) } \\
\text { Scoring Categories }\end{array}$ \\
\hline $\begin{array}{l}\text { RB 1-1 Building Envelope - } \\
\text { RETV } \\
\text { RETV value }=\quad \mathrm{W} / \mathrm{m}^{2} \\
\text { Maximum Permissible RETV = } \\
25 \mathrm{~W} / \mathrm{m}^{2}\end{array}$ & \multirow{2}{*}{$\begin{array}{l}\text { Structural System } \\
\text { 1. Precast Concrete System } \\
\text { 2. Structural Steel System } \\
\text { 3. Cast In-situ System } \\
\text { 4. Roof System }\end{array}$} \\
\hline RB 1-2 Dwelling Unit Indoor & \\
\hline $\begin{array}{l}\text { (a)(ii) Design for natural } \\
\text { ventilation (non-air conditioned) } \\
\text { - Building layout design } \\
\text { - Dwelling unit design }\end{array}$ & \multirow{3}{*}{$\begin{array}{l}\text { Wall System } \\
\text { 1. Curtain Wall / Full Height } \\
\text { Glass Partition / Dry Partition } \\
\text { Wall / Prefabricated Railing } \\
\text { 2. Precast Concrete Panel / Wall } \\
\text { 3. PC Formwork } \\
\text { 4. Cast In-situ RC Wall } \\
\text { 5. Cast In-situ RC Wall with } \\
\text { Prefab Reinforcement } \\
\text { 6. Precision Block Wall (Internal } \\
\text { Wall) } \\
\text { 7. Precision Block Wall (External } \\
\text { Wall) } \\
\text { 8. Brick-wall }\end{array}$} \\
\hline $\begin{array}{l}\text { RB 1-4 Lighting } \\
\text { (b) Day lighting in the following } \\
\text { areas: } \\
\text { (i) Lift lobbies and corridors } \\
\text { (ii) Staircases } \\
\text { (iii) Car parks }\end{array}$ & \\
\hline $\begin{array}{l}\text { RB 1-5 Ventilation in Car parks } \\
\text { (a) Car parks with natural } \\
\text { ventilation } \\
\text { (b) Staircases }\end{array}$ & \\
\hline $\begin{array}{l}\text { RB 4-1 Noise Level } \\
\text { Building design to achieve } \\
\text { ambient internal noise level as } \\
\text { specified: } \\
55 \mathrm{~dB}(6 \mathrm{am}-10 \mathrm{pm}) \text { LeqA } \\
45 \mathrm{~dB}(10 \mathrm{pm}-6 \mathrm{am}) \text { LeqA }\end{array}$ & \multirow[t]{3}{*}{$\begin{array}{l}\text { Other Buildable Design } \\
\text { Features } \\
\text { 1. Standardization } \\
\text { 2. Grids } \\
\text { 3. Others } \\
\text { 4. Single Integrated Components }\end{array}$} \\
\hline $\begin{array}{l}\text { RB 4-4 Indoor Air Quality in } \\
\text { Wet Areas } \\
\text { Provision of adequate natural } \\
\text { ventilation and day lighting in wet } \\
\text { areas such as kitchens, bathrooms } \\
\text { and toilets. }\end{array}$ & \\
\hline $\begin{array}{l}\text { RB 5-1 Green Features and } \\
\text { Innovations } \\
\text { Environmental Protection } \\
\text { (i) Use of precast toilets } \\
\text { (ii) Provision of green roof and } \\
\text { roof top garden } \\
\text { (iii) Provision of vertical } \\
\text { greening }\end{array}$ & \\
\hline
\end{tabular}




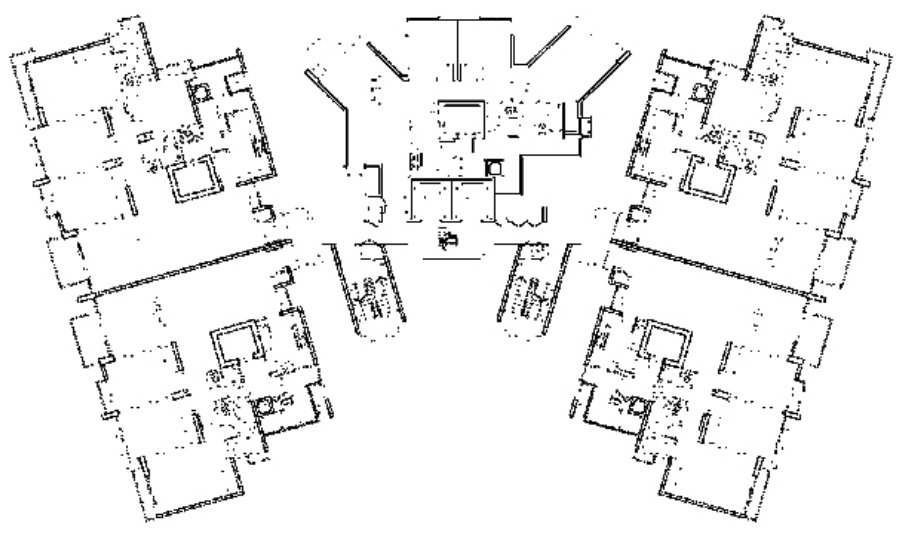

Source: Reference [1]

Figure 2. Typical floor layout

$\mathrm{L}_{\mathrm{w}}=$ Percentage of total external and internal wall length using a particular wall system

$\mathrm{L}_{\mathrm{wt}}=$ Total wall length, excluding the length of external basement wall for earth retaining purpose

$\mathrm{L}_{\mathrm{wa}}=$ External \& internal wall length using a particular wall system

$\mathrm{S}_{\mathrm{s}}=$ Labour saving index for structural system

$\mathrm{S}_{\mathrm{w}}=$ Labour saving index for external and internal wall system

$\mathrm{N}=$ Buildability Score for other buildable design features

Bonus points $=$ Bonus points for the use of single integrated components

For more details on the breakdown of the buildability scores for the three components: structural system, wall system and other buildable features, reference should be made to the Code of Practice for Buildable Design [1]. 


\section{RB1-1 BUILDING ENVELOPE - RETV}

Based on the Code for Environmental Sustainability of Buildings [5], the thermal performance of building envelope to minimize heat gain (thus reducing the overall cooling load requirement) is quantified based on the calculated residential envelope transmittance value (RETV). According to the BCA's Code on Thermal Performance for Buildings [7], the RETV involves three basic elements of heat gain through the exterior walls and windows of a building. These would include: heat conduction through opaque walls, heat conduction through glass windows and solar radiation through glass windows [7]. The Code on Thermal Performance for Buildings provides the following formula for the calculation of RETV:

$R E T V=3.4(1-W W R) U_{w}+1.3(W W R) U_{f}+58.6(W W R)(C F)(S C)$

Where:

RETV $=$ residential envelope transmittance value $\left(\mathrm{W} / \mathrm{m}^{2}\right)$

WWR $=$ window-to-wall ratio (fenestration area/gross area of exterior wall)

$\mathrm{U}_{\mathrm{w}}=$ thermal transmittance of opaque wall $\left(\mathrm{W} / \mathrm{m}^{2} \mathrm{~K}\right)$

$\mathrm{U}_{\mathrm{f}}=$ thermal transmittance of fenestration $\left(\mathrm{W} / \mathrm{m}^{2} \mathrm{~K}\right)$

$\mathrm{CF}=$ correction factor for solar heat gain through fenestration

$\mathrm{SC}=$ shading coefficient of fenestration

Based on the formula given in the Code [7], it can be observed that the RETV is dependent on the properties of the materials, like the thermal transmittance value, correction factor of solar heat gain and the shading coefficient selected by the architect to be used in the design and also, the window-to-wall ratio. In order to achieve a lower RETV to mirror the ability of the building envelope to minimize significantly the heat gain, the value of the variables found in the equation should be kept to the minimal. The variable that is related to buildability would be the windowto-wall ratio since this would affect the productive design and construction of the building. The remaining variables primarily involve the selection of the material properties. Hence, in this case study, the RETV will be modified to the desirable level and the resultant window-to-wall ratio will be determined. The remaining variables would be assumed with fixed values.

Based on the Code for Environmental Sustainability of Buildings [5], the maximum permissible or baseline RETV that is achieved by the building envelope 
should be $25 \mathrm{~W} / \mathrm{m}^{2}$ and up to 15 points can be scored with better thermal performance than the baseline standard. 3 points will be awarded for every reduction of $1 \mathrm{~W} / \mathrm{m}^{2}$. Therefore, to achieve the maximum point, there should be a reduction of $5 \mathrm{~W} / \mathrm{m}^{2}$ and the building envelope's targeted RETV should be at $20 \mathrm{~W} / \mathrm{m}^{2}$. For the purpose of this evaluation, it is assumed that the RETV is $25 \mathrm{~W} / \mathrm{m}^{2}$ for the hypothetical residential block since this is the maximum permissible value and targeted RETV is $20 \mathrm{~W} / \mathrm{m}^{2}$ in order to achieve the maximum points provided for in the GMS. Subsequently, the buildability score will be recalculated accordingly.

Since the change in RETV is $5 \mathrm{~W} / \mathrm{m}^{2}$ and assuming $\mathrm{U}_{\mathrm{w}}, \mathrm{U}_{\mathrm{f}}, \mathrm{CF}$ and $\mathrm{SC}$ are at values which are typical of residential buildings, the change in window-to-wall ratio is approximately $25 \%$. This is calculated using the formula that is stated above for RETV. In other words, in order to reduce the RETV from 25 to $20 \mathrm{~W} / \mathrm{m}^{2}$, there needs to be a reduction in the window-to-wall ratio by some $25 \%$. Consequently, there would be a reduction in coverage of windows by $25 \%$ that leads to an increase in the curtain wall length. It is proposed that the two windows of $1 \mathrm{~m} \mathrm{x} 1 \mathrm{~m}$ be reduced from each apartment unit. Correspondingly, there will be a deduction of ten windows for every storey, there being 5 apartment units on each floor.

The changes are summarized as follows:

1. Reduction of window coverage by $25 \%$ to $60 \%$ from the original $85 \%$.

2. Curtain wall length to be increased due to the decrease in window usage.

3. The additional curtain wall length would be $(1 \times 1 \times 2$ windows/unit x 5 units/floor) x 18 floors $=180 \mathrm{~m}$.

4. Table 1 is extracted from the Code of Practice on Buildable Design [1] which shows the calculation of the buildability score for the single block of residential building. The table will indicate where the changes are made after the RETV is reduced from 25 to 20 $\mathrm{W} / \mathrm{m}^{2}$.

From Table 2, the new buildability score of 79.94 points is obtained after incorporating the changes to reduce the RETV in order to achieve the maximum points possible under the GMS. This new score is a slight reduction from the initial 81 points. However, it should be noted that the reduction in RETV can also be achieved through the careful selection of glass materials for the windows which is evident from the variables in the formula for RETV. Nevertheless, this suggests that there is a possibility that requirements in the GMS can affect the BDAS score in a 
negative manner. As a result, there is a need to find out if industry practitioners are considering designs to meet the GMS and the BDAS requirements concurrently.

\section{INTERVIEW FINDINGS}

Architects were selected for the in-depth interviews because they manage the designs from the conceptualization stage to the detailed stage. Furthermore, they are also responsible for the tabulation of both the GMS and the BDAS scores before the submission of the building plans for approval by the authorities. Based on personal contacts, five architects were interviewed during the month of August and September 2009. The five interviewees have working experience ranging from 15 years to 40 years and each interviewee has at least been involved in one residential project. The reasons for not concurrently considering the designs to meet the GMS and the BDAS requirements were also explored to uncover the barriers for integration.

TABLE 1

BDAS SCORE FOR SINGLE BLOCK RESIDENTIAL BUILDING (ORIGINAL COMPUTATIONS

\begin{tabular}{|c|c|c|c|c|}
\hline Description & $\begin{array}{l}\text { Labour } \\
\text { Saving } \\
\text { Index }\end{array}$ & $\begin{array}{c}\text { Area }\left(\mathrm{m}^{2}\right) \\
\text { or Length } \\
(\mathrm{m})\end{array}$ & $\begin{array}{c}\text { Coverage } \\
(\%)\end{array}$ & $\begin{array}{c}\text { Buildability } \\
\text { Score }\end{array}$ \\
\hline \multirow{3}{*}{$\begin{array}{l}\text { Structural System } \\
\text { (1) Flat plate for apartment } \\
\text { area + Roof } \\
\text { (2) RC beam/slab for lift } \\
\text { lobby area + Roof } \\
\text { Total }\end{array}$} & $\begin{array}{l}\mathrm{S}_{\mathrm{s}}= \\
0.90\end{array}$ & $\begin{array}{c}12,272.10 \\
\mathrm{~m}^{2}\end{array}$ & $86.32 \%$ & 38.84 \\
\hline & $\begin{array}{l}\mathrm{S}_{\mathrm{s}}= \\
0.50\end{array}$ & $\begin{array}{c}1,945.60 \\
\mathrm{~m}^{2}\end{array}$ & $13.68 \%$ & 3.42 \\
\hline & & $\begin{array}{c}14,217.70 \\
\mathrm{~m}^{2}\end{array}$ & $100.00 \%$ & 42.26 \\
\hline $\begin{array}{l}\text { Use of prefabricated } \\
\text { reinforcement } \\
\text { Welded mesh for cast in- } \\
\text { situ floor slab } 86 \% \text { of total } \\
\text { floor area }\end{array}$ & 0.03 & & $86.00 \%$ & 1.29 \\
\hline Total (a) & & & & 43.55 \\
\hline
\end{tabular}




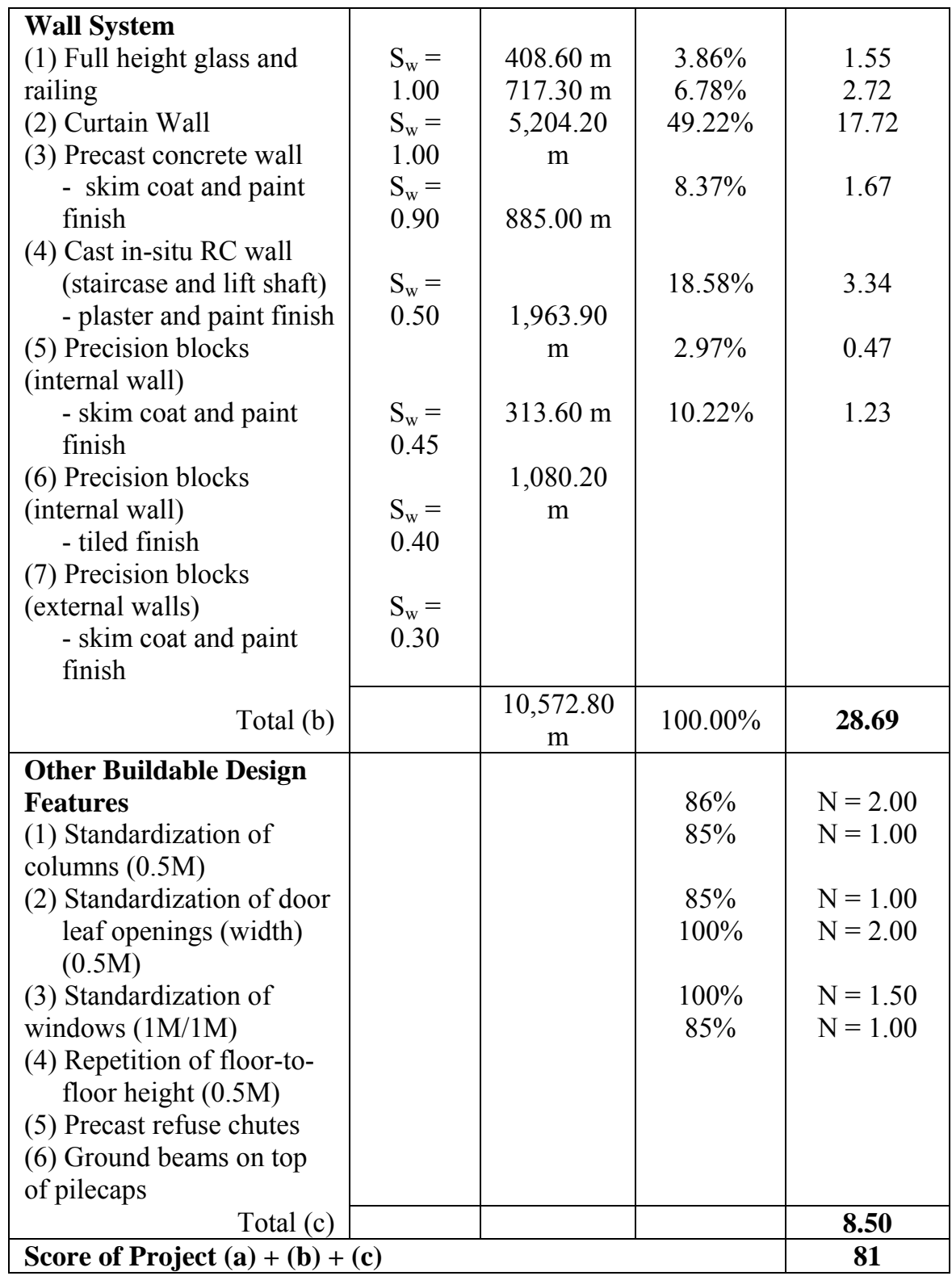

Source: Reference [1] 
https://ir.iba.edu.pk/businessreview/vol6/iss1/3

DOI: https://doi.org/10.54784/1990-6587.1180

Business Review - Volume 6 Number 1

January - June 2011

TABLE II

RECOMPUTED BDAS SCORE FOR SINGLE BLOCK RESIDENTIAL BUILDING

\begin{tabular}{|c|c|c|c|c|}
\hline Description & $\begin{array}{c}\text { Labour } \\
\text { Saving Index }\end{array}$ & $\begin{array}{l}\text { Area }\left(m^{2}\right) \text { or } \\
\text { Length }(m)\end{array}$ & Coverage (\%) & $\begin{array}{c}\text { Buildability } \\
\text { Score }\end{array}$ \\
\hline $\begin{array}{l}\text { Structural System } \\
\text { (1) Flat plate for apartment area + Roof } \\
\text { (2) RC beam/slab for lift lobby area + Roof }\end{array}$ & $\begin{array}{l}\mathrm{S}_{\mathrm{s}}=0.90 \\
\mathrm{~S}_{\mathrm{s}}=0.50\end{array}$ & $\begin{array}{l}12,272.10 \mathrm{~m}^{2} \\
1,945.60 \mathrm{~m}^{2}\end{array}$ & $\begin{array}{l}86.32 \% \\
13.68 \%\end{array}$ & $\begin{array}{c}38.84 \\
3.42\end{array}$ \\
\hline Total & & $14,217.70 \mathrm{~m}^{2}$ & $100.00 \%$ & 42.26 \\
\hline $\begin{array}{l}\text { Use of prefabricated reinforcement } \\
\text { Welded mesh for cast in-situ floor slab } 86 \% \\
\text { of total floor area }\end{array}$ & 0.03 & & $86.00 \%$ & 1.29 \\
\hline Total (a) & & & & 43.55 \\
\hline $\begin{array}{l}\text { Wall System } \\
\text { (1) Full height glass and railing } \\
\text { (2) Curtain Wall } \\
\text { (3) Precast concrete wall } \\
\text { - skim coat and paint finish } \\
\text { (4) Cast in-situ RC wall } \\
\text { (staircase and lift shaft) } \\
\text { - plaster and paint finish } \\
\text { (5) Precision blocks (internal wall) } \\
\text { - skim coat and paint finish } \\
\text { (6) Precision blocks (internal wall) } \\
\text { - tiled finish } \\
\text { (7) Precision blocks (external walls) } \\
\text { - skim coat and paint finish }\end{array}$ & $\begin{array}{l}\mathrm{S}_{\mathrm{w}}=1.00 \\
\mathrm{~S}_{\mathrm{w}}=1.00 \\
\mathrm{~S}_{\mathrm{w}}=0.90 \\
\mathrm{~S}_{\mathrm{w}}=0.50 \\
\mathrm{~S}_{\mathrm{w}}=0.45 \\
\mathrm{~S}_{\mathrm{w}}=0.40 \\
\mathrm{~S}_{\mathrm{w}}=0.30\end{array}$ & $\begin{array}{c}408.60 \mathrm{~m} \\
897.30 \mathrm{~m} \\
5,204.20 \mathrm{~m} \\
\\
885.00 \mathrm{~m} \\
\\
1,963.90 \mathrm{~m} \\
313.60 \mathrm{~m} \\
1,080.20 \mathrm{~m}\end{array}$ & $\begin{array}{c}3.80 \% \\
8.34 \% \\
48.40 \% \\
\\
8.23 \% \\
\\
\\
18.26 \% \\
2.92 \% \\
\\
10.05 \%\end{array}$ & $\begin{array}{c}1.52 \\
3.34 \\
17.42 \\
\\
1.65 \\
\\
\\
\\
3.29 \\
0.47 \\
\\
1.21\end{array}$ \\
\hline Total (b) & & $10,572.80 \mathrm{~m}$ & $100.00 \%$ & 28.89 \\
\hline $\begin{array}{l}\text { Other Buildable Design Features } \\
\text { (1) Standardization of columns }(0.5 \mathrm{M}) \\
\text { (2) Standardization of door leaf openings } \\
\quad \text { (width) }(0.5 \mathrm{M}) \\
\text { (3) Standardization of windows }(1 \mathrm{M} / 1 \mathrm{M}) \\
\text { (4) Repetition of floor-to-floor height }(0.5 \mathrm{M}) \\
\text { (5) Precast refuse chutes } \\
\text { (6) Ground beams on top of pile caps }\end{array}$ & & & $\begin{array}{c}86 \% \\
85 \% \\
\\
60 \% \\
100 \% \\
\\
100 \% \\
85 \%\end{array}$ & $\begin{array}{l}\mathrm{N}=2.00 \\
\mathrm{~N}=1.00 \\
\mathrm{~N}=0.00 \\
\mathrm{~N}=2.00 \\
\mathrm{~N}=1.50 \\
\mathrm{~N}=1.00\end{array}$ \\
\hline Total (c) & & & & 7.50 \\
\hline \multicolumn{4}{|l|}{ Score of Project (a) $+(b)+(c)$} & 79.94 \\
\hline
\end{tabular}

Source: adapted from Reference [1] 
Most of the interviewees expressed that they do consider designs for the GMS and the BDAS concurrently but upon further probing, seems to show otherwise. This can be seen through the allocation of work within the team of architects during the design conceptualization stage where different architects take charge of the design considerations for the GMS and the BDAS separately and the final decision would be made by the lead architect in charge of the project. This would seem to suggest that it is not possible to design concurrently to meet both the GMS and the BDAS requirements. According to Interviewee C,

"In my office, different people do it. The more experienced one will do the BDAS. It's just allocation of work, just happen to be I was the one who is doing the Green Mark but not BDAS. My architect in charge, the Senior Project Manager, she knows what's happening. But for me, I'm a junior at that time, so I only do the Green Mark so I know roughly what it's [BDAS] about but I didn't go into it."

Interviewee $\mathrm{E}$ expressed that the design considerations are done by different architects or members in the team,

"Usually, this is the case because in a team you have different people, you have the technical people, the architects, the assistants, and the draftsman so we will have to work together but one person will make the overall decision.

Furthermore, it seems that having to comply with both sets of legislative requirements come across as a paper exercise rather than to have a genuine concern to design to meet the requirements for both environmental sustainability and buildability concurrently. According to Interviewee D,

"When you do all these things, you're just wanting to get marks and it always meeting all these mandatory points that you say pass or fail, before we can do our submission and it becomes, like what I've said, a theoretical exercise and then along the way, skim a bit here and there. There's this aspect of trying to look at the requirements and making your building work towards it."

In addition, Interviewee D expressed that,

"The technical people will do the calculation of the scores. So we will work on the designs and they'll check and look into the different design areas. Those that do not comply will be reported and we'll see how we can allocate something so that the points can be increased to achieve the required score."

Hence, this lack of genuine concern and treating it as a "theoretical exercise" does not seem to be conducive to designing for the GMS and the BDAS concurrently. In addition, meeting the minimum requirements for the GMS and the 
BDAS does not appear to be of a great concern as the tabulation for these scores are done at the end of the design development stage by the technical staff within the team of project architects. Unless the requirements are not met, the designs will not be modified. This seems to suggest that whether such requirements are met would be of secondary importance relative to the original design.

Based on the feedback from most of the interviewees, it appears that designers do not consider the designs for the GMS and the BDAS concurrently in order to meet minimum requirements. With this observation, the reasons for this mode of operation would be further examined.

One reason cited for not considering the design requirements for the GMS and the BDAS concurrently is due to the short time period since the GMS has been mandated when compared to the BDAS which was mandated in 2001. Hence, designs that have been drawn up just before the GMS were mandated could have been considered concurrently with the BDAS. According to Interviewee C,

"GM is quite a new thing, it came out about 4 years ago, if I remember correctly. BDAS is about 10 years ago. So when GM came out there was a lot of reeducation...BDAS is mandatory, it is a must. At that time GM wasn't but now it is ... because it is new, and new buildings take a long time to build and all that, so when the project started it is hard to come back already. You know like when you usually design and it goes on and you suddenly have to put all these [requirements] in, of course they give you a period of time where you can have a buffer. You know they give you a buffer period. So when I worked on the project then I got to be more familiar with this (for Green Mark). BDAS was...I know BDAS is a requirement but it just happened that it wasn't done by me at that time...for this project I was working on."

The points that have earlier been mentioned above can also be seen as the reasons for not considering both the GMS and the BDAS concurrently even though the requirements can affect one another. This is because the work allocation is planned in such a way that does not allow this to take place. Based on the response from Interviewee $\mathrm{C}$, it appears that the design considerations for the GMS and the BDAS were undertaken by different persons within the project team. According to Interviewee $\mathrm{C}$,

"So I remember we were working together, but we didn't communicate too much, so it was just that this part someone calculates then we will come back at the end."

Hence, the lack of communication between the designers seems to be the reason for not having both sets of design requirements considered concurrently and 
also prevent parties from seeing how designs for the GMS could affect those for the BDAS.

Furthermore, depending on the size of the firm, architects might not be involved in the computation for the GMS and the BDAS and these are left to the responsibility of the technical staff. In the case of Interviewees $\mathrm{C}$ and $\mathrm{E}$, the tabulation of both scores is undertaken by the technical staff. For Interviewee D, the technical staff will tabulate the BDAS score whereas the GM score may be undertaken by the architect in charge. According to Interviewee D,

"Usually in big firms like ours, we have people who are specialized in doing things, for buildability score, our guys, the technical staff will work on it but for GM, still at a design level stage, the architects will play a bigger role that means to decide over what is to be taken up. In terms of calculation it is very easy also. Architects can usually do that. But for buildability, I think it is quite easy, it's just that it is very tedious. You know, spending the architect's time, it is very tedious, you start measuring, wall, floor, columns for every part of the building."

Most of the architects interviewed also agreed that in the near future, more importance could be given to designs for the GMS rather than the BDAS. Most of them also agreed that the mandated requirements from these two domains might affect one another; however, the extent of it would not be too great as the areas concerning the designs for the GMS appears to be different from the BDAS. According to Interviewee $\mathrm{E}$,

"Green Mark is more on the compliance of $M \& E$ and energy. So it is not so much of buildability. Buildability is more on the aesthetics, construction methods."

Interviewee D expressed that,

"I think GM probably encompasses more. Buildability focuses only on...of course it focuses on the design stage and it focuses on the practicality during site construction so really it's only these two areas I think."

Hence, this suggests another reason for the lack of concurrent design considerations because the designers view it as different entities which do not affect one another significantly. Interviewee $\mathrm{C}$ also suggested that the requirements for "BDAS is more simple than GM". In addition, Interviewee $\mathrm{C}$ believed that the designs for the GMS will complement the BDAS and therefore whether these designs are considered alongside each other does not seem to pose a grave issue. According to Interviewee C, 
"It doesn't affect each other in fact I think it complements each other even if it is separated it is ok. Because when we did the BDAS, all the wall system being modular and all, prefab and all helps us in the Green Mark score. Because under the green mark category you have the pre-fabricated bathrooms, you know under the special item, the bonus marks, under that item it helps us. And we use dry wall also; modular kind of thing, internal partitions, and this also helps us to score in the green mark. So actually they complement each other so even if they are considered separately, it is ok because they don't affect each other."

This could perhaps be the most crucial reason for the lack of integration in the designs for the GMS and the BDAS as the impact on one another does not warrant the attention to do so. Furthermore, with the possibility of impacting each other positively, this seems to suggest that there is no significant need to consider the designs for these two sets of mandatory requirements simultaneously.

In particular, it appears not to be too difficult to fulfill the minimum requirements, according to Interviewee $\mathrm{D}$,

"A lot of these designs that we churn out during the design stage, it's quite standard. For example, you need to have certain requirement for ETTV, a lot of these technologies are out there it's quite common, so you specify it accordingly and meet these requirements and naturally at that point, it is a given. We don't need to fight for it."

Therefore, having to meet minimum requirements does not pose as great a challenge and hence importance would be placed on other aspects of the design. Moreover, there is the mindset that the GMS and the BDAS do not affect each other greatly and hence, naturally designers are not inclined to consider these designs concurrently. This also seems to suggest that there could possibly be unequal importance placed on designing buildings for the GMS and the BDAS currently.

This difference in importance could be attributed to the increasing emphasis given by the authorities in the development of buildings to meet environmental sustainability where the government is giving more incentives and benefits to the developers and the contractors. This reason was supported by Interviewee A. The $2^{\text {nd }}$ Green Building Master Plan, for example, includes a new incentive scheme [6]: Green Mark Gross Floor Area (GM GFA) Incentive Scheme which awards additional gross floor area to developers who have earned higher-tier Green Mark awards for new buildings and reconstruction projects. In addition, the $\$ 100$ million Green Mark Incentive Scheme for Existing Buildings (GMIS-EB) added another push in this direction. With these in mind, there is no doubt that the developers will give more attention to fulfilling the requirements for the GMS, thus down playing the BDAS. All the interviewees agreed that greater emphasis is being given to the 
GMS than the BDAS and according to Interviewee A, it is "improving and increasingly" the case. Such greater importance given to the GMS was placed solely because of the incentives given. Interviewee B expressed that,

"Probably in the long run, GM should be the one that takes precedence because there are many very basic physical things people can or architects can, employ physical means which can save the very nature of the earth. But GM yes, it is unfortunately heading into a place where there are floods, hurricanes and everything else. We want to cut down on all that we have been abusing the world too much. Yes I agree that it is important over buildability."

On the other hand, Interviewee D opined that,

"Well let's just say green mark is the flavor of the day right now, the fashion of this big decade or so and after a while green mark will naturally become a norm, very much like buildability... Buildable design I think it is very stable, I don't think it will have that influence that they had years ago, I think there's so much more we can do with buildability but of course with new technology basically the appraisal system will be suited to the technology that is coming."

The only exception given would be from Interviewee A who believed that there should be equal importance placed in the design considerations for the GMS and the BDAS. According to Interviewee A,

"There is equal importance, we will achieve as much as we can, as I have said they help each other so if you can score well in buildability score, you can also score well in green mark so definitely, we can score the best for both unless there is a design or site constraint. Because the site is a rectangular site so the long side happens to face west so we don't want to change our concept design to be a square block or round block, we want a linear one so for that one we don't score. We give up. In the end, we will balance up with other items. Because the design concept is why we are appointed architect for the project so that we can't change the concept design."

Furthermore, based on the response from Interviewee A, this seems to suggest that any difference in importance placed would be due to the requirements of the client. Accordingly, Interviewee A shared that

"This was stated right at the start when it [project] was awarded to us, they [developer] would tell us it is ear marked for green mark and it was ear marked for all these awards." 
As the developer or the client has the final decision in the project, architects will be following the instructions given by their paymasters. Hence, it comes as no surprise that there is a changing emphasis in design considerations. Hence, according to Interviewee D who indicated that the GMS is the "flavour of the day" right now, developers are more likely to require more design considerations for the GMS than the BDAS. Hence, architects are also more likely to just meet the minimum requirements for BDAS and to try to achieve higher GM score when requested by their clients.

\section{CONCLUSION}

With the reasons that have been identified from the responses of the interviewees, it seems that the architects do not think that it is necessary to consider the requirements for the GMS and the BDAS concurrently. The reason cited by Interviewee $\mathrm{E}$ is that both sets of mandated requirements do not have the same objective. The BDAS aims to look at designing the building for modularity and adopting methods of construction for buildability whereas the GMS considers the designs of the components in the building for environmental sustainability. Since these are two different facets of construction, despite being related, it may not be possible to design for these two areas concurrently. In addition, Interviewee $\mathrm{C}$ believed that

"...they complement each other so even if they are considered separately, it is ok because they don't affect each other. It doesn't undercut or what, I don't think so...

“...then architects don't have to go through two exams, just go through once and pass everything. It's not a bad idea. But will it dilute the focus for what it's meant to be? Maybe you don't even need buildability score; you just integrate into green mark. Because it's related, like I said, if you score points for BDAS you will score points for GM"

Nevertheless, Interviewee $\mathrm{C}$ observed that the requirements for the BDAS could be integrated into the GMS so that there would only be one set of requirements to fulfill which could possibly lead to greater efficiency. However, Interviewee C pointed out that there might be a possibility of "diluting the focus of what [the requirements are] meant to be". Hence, even with the integration, this possibility should be kept in mind.

Although it seems that the designs for the GMS and the BDAS may affect one another based on technical calculations of their respective scores, the two Codes spelling out the GMS and the BDAS may also be complementary, as suggested by one of the interviewees. Hence, there can be an integration of the two Codes of 
Practice $[1,5]$ to bring about greater efficiency and also to achieve more holistic benefits of buildings not just in terms of environmental sustainability but also better productivity through buildability. After the case study which involves the technical aspects of calculating the scores have been discussed, the non-technical issues were examined through interviews with practicing architects. The same conclusion can be drawn from the case study and interviews, that the effects that the GMS requirements have on the BDAS may not be significant due to the different objectives for the two Codes $[1,5]$ with different considerations. Furthermore, should there be any negative influence, the effect may not be that great enough to warrant the integration of the two Codes. There appears to be a lack of a strong driver required for the integration of the two Codes to motivate practitioners to consider the designs for the GMS and the BDAS concurrently. The related issues are:

1. People. Building designers do not see the need to consider the designs for the BDAS and the GMS concurrently and such practice seems to be lacking in the industry. One interviewee has also expressed that there is a lack of skills to do so should there be established that there is such a need to progress in this direction.

2. Projects. In addition, work is typically allocated to different parties in the design team amongst the architects and engineers. This appears to render communication amongst the building designers ineffective and results in a barrier to designing for the GMS and the BDAS requirements concurrently.

3. Systems support integration. There is also the lack of availability of suitable softwares that can aid the building designer to consider the BDAS and GMS requirements simultaneously during the design.

From the interviews, it seems that for integrative practices to be successfully implemented, the trigger will need to be government or client-led. Hence, the effectiveness of integrating the design requirements of the GMS and the BDAS should be looked into and to highlight the possibilities of any benefits that can be derived from there so that there can be more incentives for building designs to adopt such an integrative practice.

The case study presented in this paper is only limited to two criteria under the "Energy efficiency" category of the GMS. In order to have more conclusive results of the effects that the mandatory requirements of the GMS have on the BDAS, the rest of the requirements should also be examined further. One particular area to look into would be the requirements for "Sustainable Construction" in "Part 3 Environmental Protection" in the Code for Environmental Sustainability of Buildings [5]. In addition, different types of developments and different building types may 
result in different outcomes for the GMS and the BDAS. Hence, there is also a need to look into the non-residential buildings and to evaluate the effects these two design parameters have on each other. Furthermore, a cost and benefit analysis can also be undertaken to examine if it is beneficial to the industry to implement a new set of criteria which encompasses both the BDAS and the GMS.

In the final analysis, the study suggests that issues relating to integration management for green business are not as simplistic as these may seem to be initially.

\section{ACKNOWLEDGEMENT}

This study would not be possible without the kind assistance as well as the generosity of the architects who have freely given of their time to share their views on integrating BDAS and GMS in their building designs as part of the green business agenda.

\section{REFERENCES}

1. Building and Construction Authority, Code of Practice on Buildable Design, Singapore, 2005. Retrieved 13 July 2009 from: http://www.bca.gov.sg/BuildableDesign/others/copbdsep05.pdf

2. Ministry of Environment and Water Resources, State of the Environment 2008 Report Singapore, Singapore, 2008. Retrieved 25 September 2009 from:http://app.mewr.gov.sg/data/imgcont/1233/026039\%20Climate\%20C hange.pdf

3. Building and Construction Authority, BCA launches Green Mark for Buildings Scheme, Singapore, 2005. Retrieved 22 September 2009 from: http://www.bca.gov.sg/Newsroom/others/pr110105.pdf

4. Building and Construction Authority, Legislation on Environmental Sustainability for Buildings, Singapore, 2007. Retrieved 25 September 2009 from: http://www.bca.gov.sg/EnvSusLegislation/Environmenta Sustainability Legislation.html

5. Building and Construction Authority, Code for Environmental Sustainability of Building, Version 1.0, Singapore, 2008. Retrieved 13 July 2009 from: qhttp://www.bca.gov.sg/EnvSusLegislation/others/Env_Sus_Code.pdf 
6. Building and Construction Authority, Media Release on "BCA's $2^{\text {nd }}$ Green Building Master Plan - 80\% of buildings will be green by 2030”, Singapore, 2009. Retrieved 3 October 2009 from:

http://www.bca.gov.sg/newsroom/others/pr270409.pdf

7. Building and Construction Authority, Code on Thermal Performance for Buildings, Singapore, 2000. Retrieved 3 December 2009 from: http://www.bca.gov.sg/PerformanceBased/others/RETV.pdf

Appendix A

Framework For Gms - Residential Buildings

Table 4.1.1(a) : Framework and Point Allocations for Residential Building Criteria

\begin{tabular}{|c|c|c|c|}
\hline \multicolumn{3}{|r|}{ Category } & Point Allocations \\
\hline \multicolumn{4}{|c|}{ (I) Energy Related Requirements } \\
\hline \multirow{3}{*}{ 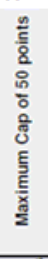 } & \multirow{4}{*}{$\begin{array}{l}\frac{g}{2} \\
\frac{5}{8} \\
\frac{8}{2} \\
\text { ह } \\
\frac{5}{E} \\
\frac{E}{2}\end{array}$} & \multicolumn{2}{|l|}{ Part 1 : Energy Efficiency } \\
\hline & & $\begin{array}{l}\text { RB 1-1 Building Envelope - RETV } \\
\text { RB 1-2 Dwelling Unit Indoor Comfort } \\
\text { RB 1-3 Natural Ventilation in Common Areas } \\
\text { RB 1-4 Lighting } \\
\text { RB 1-5 Ventilation in Carparks } \\
\text { RB 1-6 Lifts } \\
\text { RB 1-7 Energy Efficient Features }\end{array}$ & $\begin{array}{l}15 \\
16 \\
2 \\
15 \\
8 \\
2 \\
7\end{array}$ \\
\hline & & Category Score for Part 1 - Energy Efficiency (Exclude Bonus Points) & 65 \\
\hline 证 & & RB 1-8 Renewable Energy (Bonus Points) & 20 \\
\hline \multicolumn{4}{|c|}{ (II) Other Green Requirements } \\
\hline \multirow{15}{*}{ 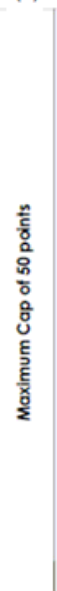 } & \multirow{15}{*}{ 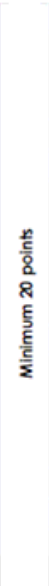 } & \multicolumn{2}{|l|}{ Part 2: Water Efficiency } \\
\hline & & $\begin{array}{l}\text { RB 2-1 Water Efficient Fittings } \\
\text { RB 2-2 Water Usage }\end{array}$ & $\begin{array}{c}10 \\
1 \\
2\end{array}$ \\
\hline & & $\begin{array}{l}\text { RB 2-3 Irrigation System } \\
\text { Category Score for Part 2-Water Efficiency }\end{array}$ & $\begin{array}{c}2 \\
13\end{array}$ \\
\hline & & \multicolumn{2}{|l|}{ Part 3 : Environmental Protection } \\
\hline & & $\begin{array}{l}\text { RB 3-1 Sustainable Construction } \\
\text { RB 3-2 Greenery } \\
\text { RB 3-3 Environmental Management Practice } \\
\text { RB 3-4 Public Transport Accessibility }\end{array}$ & $\begin{array}{l}12 \\
6 \\
9 \\
2\end{array}$ \\
\hline & & Category Score for Part 3 - Environmental Protection & 29 \\
\hline & & \multicolumn{2}{|l|}{ Part 4 : Indoor Environmental Quality } \\
\hline & & RB 4-1 Noise Level & 1 \\
\hline & & RB 4-2 Indoor Air Pollutants & 3 \\
\hline & & RB 4-3 Waste Disposal & 1 \\
\hline & & RB 4-4 Indoor Air Quality in Wet Areas & 1 \\
\hline & & Category Score for Part 4 - Indoor Environmental Quality & 6 \\
\hline & & \multicolumn{2}{|l|}{ Part 5 : Other Green Features } \\
\hline & & RB 5-1 Green Features \& Innovations & 7 \\
\hline & & Category Score for Part 5 - Other Green Features & 7 \\
\hline & & $\begin{array}{r}\text { Total Points Allocated : } \\
\text { Total Point Allocated (Include BONUS points): }\end{array}$ & $\begin{array}{l}120 \\
140\end{array}$ \\
\hline & & Green Mark Score (Max) : & $100+$ Bonus 20 points \\
\hline
\end{tabular}

Source: Reference [5] 
Private ownership of the means of production in a highly industrialized economy has produced the modern corporation, through which the financial resources of large numbers of people are pooled, ownership and management are separated, and vast enterprises launched and operated. Given the central place of the private corporation in our institutional life, the ideals and standards of management, in particular management's conception of the social obligations of the corporation, will have a great deal to do with the kind of society in which we live. In recent times, the strategic place of the corporation has presented management with a new problem: whether to construe the role of the corporation narrowly as a strictly amoral business enterprise organized to maximize profits, or to accept a broader, socially oriented interpretation of the responsibilities of the corporation that would include the welfare of the community.

Harry K. Girvetz, Editor, Contemporary Moral Issues pg 197 